\title{
Specialization and Career Dynamics: Evidence from the Indian Administrative Service
}

\author{
John-Paul Ferguson* \\ Stanford University
}

Sharique Hasan

Stanford University

* Corresponding author.jpferg@stanford.edu. The authors would like to thank Surendrakumar Bagde, Rodrigo Canales, Roberto Fernandez, Barbara Lawrence and Ezra Zuckerman; seminar participants at UC-Berkeley, MIT Sloan and Stanford GSB; and participants of the $11^{\text {th }}$ Organizational Ecology Conference (Lugano) and the $4^{\text {th }}$ People \& Organizations Conference (Wharton) for their assistance, comments and suggestions. Any mistakes that remain are the authors.

\begin{abstract}
In this article, we attempt to resolve the tension between two sets of conflicting hypothesizes about the role of specialization in workers' careers. Some scholars argue that specialization is a net benefit that allows workers to get ahead, while others argue that broad experience across several domains is the only way to be truly exceptional. We use remarkably rich longitudinal data on the careers of Indian Administrative Service officers, members of the Republic of India's elite bureaucratic service to test both these hypotheses. We find that specialization benefits officers throughout their career. However, multiple theoretical accounts are consistent with this effect. One account suggests that specialization benefits workers because it gives them skills that make them more productive, while another suggests that specialization is a signal of ability and promise. Our analysis indicates that both accounts are valid, but apply at different stages of officers' careers. The skills acquired through specialization matter more in the later career; in the early career, specialization is mainly a signal.
\end{abstract}




\section{Introduction}

Organization theory gives conflicting career advice about specialization. There are advantages to focusing on one thing. Whether it is because of skill that one learns on the job or because of the clearer signals of identity that one sends to potential employers, specializing can help you get ahead. Yet there are advantages to broad experience. These might accrue from developing different skills, or might be due to brokering between different domains of expertise. In recent years there have been efforts to see which of these effects predominates (Acemoglu \& Pischke 1999a,b; Autor 2001; Booth, Francesconi \& Frank 2002; Zuckerman, Kim, Ukanwa \& Von Rittman 2003), but such research faces two major hurdles. First, there are empirical difficulties of measuring the effects of specialization. These include unobserved differences in ability and self-selection, which can be correlated with specialization; and survivor bias, produced when getting new experience takes a person out of a dataset. Most studies find that specialization is a net benefit for workers. Yet, second, even if there is causal evidence for benefits from specializing, multiple theories predict this result. We must then explore mechanisms to understand why this happens. In the simplest case, specialization can reflect real skills (Becker 1962, Rosen 1972, Mincer \& Jovanovic 1981). Sociological accounts emphasize instead that specialization can be a signal of general competence, divorced from the specific skills acquired (Zuckerman et al. 2003).

Overcoming these hurdles requires data with specific features. In this paper, we use an unusually rich set of longitudinal data about the background, work experiences and career outcomes of officers in the Indian Administrative Service (IAS) to parse the effect of specialization on career advancement. These data help us with both of these problems. First, the structure of the IAS minimizes variance in unobserved ability and rules out selfselection and survivor bias. This allows us to estimate more convincing, causal benefits of specialization on career advancement. Indeed we find that specialization is a benefit for IAS officers at all stages of their careers. Second, the IAS data include information about skills its officers acquire in each job, as well as the skill requirements of each job. Thus we can distinguish between skill-based and signal-based mechanisms that relate specialization to promotion, by exploring the match (or lack thereof) between the skills an officer acquires and the jobs to which they are promoted. We find that both mechanisms operate, but at different points in the career. Specialization is rewarded later in officers' careers because of the skills they acquire by specializing. Earlier in their careers, skills are less important; it appears that specialization benefits officers because it is a signal of general ability. These results contradict studies that find that specialization helps early in careers but fades with experience, but also call into question the idea that specialization always reflects accumulated skill. Our results support both types of theories, but suggest important scope conditions for when one mechanism or the other is likely to dominate.

\section{Specialization and Careers}


Specialization has been an important topic both in labor economics (Rosen 1983, Neal 1998, Acemoglu \& Pischke 1999b, Autor 2001) and in the sociology of work (Arthur \& Rousseau 1996, Cappelli 1999, Osterman \& Burton 2004). It has been linked both to individual career outcomes and to aggregate outcomes such as labormarket inequality (Leahey 2007). In studying specialization's role, scholars offer two main theoretical accounts for why it affects performance. The first account is based on skill: specializing gives employees more time to acquire job-specific skills (Parsons 1972). The second account is based on signaling: staying in one job rather than moving between jobs signals to employers that the employee is sufficiently reliable to risk hiring (Zuckerman et al. 2003). These two accounts are often put forward as competing mechanisms, but we argue that there is no $a$ priori reason that they cannot both affect a career, and indeed that they interact with one another.

The skill account stems from economic theories of human capital and training. People build skills on the job (Becker 1962, Rosen 1972). Specializing in one type of work gives a worker the chance to build more skills than a worker who moves between types of work. When an employer considers two workers who have the same tenure and differing specialization, the employer should prefer the more specialized worker, because they will be more productive. This idea has been proposed both by scholars studying promotion in internal labor markets (Doeringer \& Piore 1971, Wholey 1985, Zuckerman 2005) and by research on hiring in external labor markets (Autor 2001). For this prediction to hold, though, the job in question should be one that uses the skills that the specialized employee has acquired.

Accounts based on skill accumulation also presume that employers have few problems assessing how much skill a given worker has. Yet research on promotion in firms, stemming for example from agency theory, suggests that separating workers' true performance from their own claims and others' evaluations of them is actually rather difficult: "Ability is initially uncertain but is learnt by the by the manager and firms over time....The manager, recognizing that performance acts as a signal of productivity, and hence will affect future compensation, will adjust her actions to influence the evaluation of her ability" (Borland 2006). Given that an employee can and has incentive to game perceptions of their performance, being in an internal labor market by itself is not enough to remove uncertainty about workers' potential ability (Ishida 2004, 2006). This skepticism about evaluating employee ability within the firm dovetails with recent scholarship on hiring that highlights the problems employers have assessing how much skill an applicant has: "[E]mployers may be unable to ascertain whether a worker actually possesses these skills, or in what amount or quality" (Acemoglu \& Pischke 1999b, p. 556). To reduce uncertainty, employers often use career histories - the sets of jobs workers have held- to help them decide about hiring and promotion (Wholey 1985, Neal 1998). Career histories give signals about how much general and specific skill a worker has (Autor 2001, Booth et al. 2002). A career history containing many diverse jobs implies a worker with less skill and ability than a career history with longer stretches of one type of work. Thus employers prefer to hire and promote employees with more specialized work histories, meaning those who 
have done fewer different types of work in a given amount of labor-market tenure (Neal 1998). Prospective employees with more specialized career histories receive higher-wage offers than employees with more diverse career histories (Acemoglu \& Pischke 1999a), and specialized employees are more likely to be retained and better compensated (Simmons \& Berri 2006).

The skill approach thus assumes that career histories unproblematically reflect accumulated skill. This assumption can produce anomalies. A history of performing many jobs could reflect prodigious skill, but several studies have found that employers often discount this possibility. When studying temporary work agencies, for example, Ward, Grimshaw, Rubery \& Beynon (2001) found that the agency had reservations about placing highly skilled workers on project teams across multiple organizations, because the resulting placement record might make the worker less appealing to future clients. Bidwell \& Fernandez-Mateo's (2010) study of a large staffing firm meanwhile found that the workers and clients needed considerable time to gauge the fit of the worker to the job and to negotiate pay accordingly, which suggests that the quality signal sent by career specialization is a noisy one at best.

The signaling approach does not assume that career histories unproblematically reflect ability. You could be a high-ability worker and thus excel at different types of jobs, but if employers interpret career histories in the way economists suggest then your movement between jobs could easily be mistaken for incompetence. There could be observed rewards for career specialization, not because specialization clearly signals ability, but because diversification unclearly signals ability. This approach departs from Spence's (1973) theory by arguing that the best signal of high quality is hard to distinguish from the signal of low quality, which breaks the relationship between signal and skill and limits the usefulness of such signals to produce efficient outcomes. The general idea is that it is hard for market participants to make sense of actors with more diffuse identities (Zuckerman 1999, Zuckerman 2000, Hsu 2006). This approach assumes that hiring specialized workers is a satisficing rather than an optimizing tactic by employers (Zuckerman et al. 2003). Employers would rather hire workers who are skilled at many things, but a varied work history is an ambiguous signal: a worker with a diverse history could be multitalented or untalented. Better, then to hire a worker with specialized experience.

Both the skill and the signaling account make the same prediction: specialization should lead to faster career progress. This makes it impossible to distinguish between the two accounts based on that relationship alone. We think that one way to distinguish them would be to leverage the fact that these mechanisms should apply more at different times in a worker's career. Most human-capital research finds that skills are accumulated relatively slowly, and skill accumulation should differentiate workers more later in their careers, when they have had time to develop more and different skills (Parsons 1972). It is harder to argue that specific skills should distinguish early-career workers, because early-career workers do not have many specific skills (Zuckerman et al. 2003). Furthermore, employers have less information about newer workers than more senior ones. Signals about general ability should be more important for less-experienced workers. It is important to note how these two 
mechanisms can interact with one another. Novice workers might specialize to show general reliability, but in so doing they acquire more specific skill; and that skill in turn is an incentive toward further specialization based on substantive experience. This integration suggests that specialization should matter both early and later in a worker's career. It also suggests though that there should be weak matches between what a worker specializes in and the job to which they are promoted early in their careers, and strong matches later.

Testing this prediction is a non-trivial task. Doing so requires data on the types of work people do throughout their careers and whether they clear comparable career hurdles. Crucially, the variance in their specialization should not be correlated with their unobservable levels of innate ability, the type of work that they do or their own preference for or against specializing. The setting should also be one where there are no organizational or other norms against diversification, lest the deck be stacked against one result. We have data from such an environment in which to test our predictions: the careers of officers in the Indian Administrative Service.

\section{Careers in the Indian Administrative Service}

Indian Administrative Service (IAS) officers are federal employees who are tasked with running a variety of government organizations - managers of managers, in effect. Officers are assigned to states ("Cadres," in IAS parlance) but can fill postings either in those states or with the central government in New Delhi. Since its formation in 1946, the IAS has been considered one of the most prestigious careers in India.

\section{Recruitment and early career}

IAS officers are recruited through a highly competitive selection process:

More than 200,000 people take the first phase of the examinations, a number that is winnowed down to some 12,000 when the final exam is held six months later. Of those, only 2,000 or so will be invited to an interview, and then only about 80 people will be offered posts with the service... (Gargan 1993).

Once admitted, officers enjoy life tenure. Most receive some initial training at the National Academy of Administration in Massoorie. Officers are then assigned to a cadre (Most cadres correspond to Indian states; some of the very small northeastern states and union territories are grouped in single cadres). Virtually all start as a sub-magistrate, managing the taxes and other affairs of a small district. Junior IAS officer work includes enforcing laws or managing local development projects. Once they are promoted to the senior pay-scale, officers are posted to sundry positions within their cadre that include managing districts, public enterprises, and 
government ministries. In each post, officers gain experience in substantive areas such as finance, rural development, or human resource management.

The specialization of an IAS officer's experience can vary widely. Most officers enter the service with little substantive preparation (Krishna 2010, p. 435). Because the IAS is a general-management service, officers are rotated through many organizations. During each posting, officers acquire one of several dozen "major experiences," such as rural development, finance, or forestry. A distinctive feature of the IAS's career-tracking system is that it records the major experience type of each job. This is useful for our study design because it allows us to track officers' movement between different types of work separately from their movement between different jobs.

Changes in postings occur at fixed intervals and most officers switch experiences frequently (Potter 1986, Krishna 2010). Qualitative evidence suggests that senior officers rotate junior ones with little concern for any emerging specialty, particularly early in the juniors' careers. Postings are primarily made according to the needs of the bureaucracy, the officers' location on the seniority scale and the availability of vacancies at that level. Therefore junior IAS officers have little control over where their next posting will be (Jayapalan 2001, p. 381):

The IAS remains, at the present time, very likely the largest cadre of generalist managers anywhere in the world...the IAS officials continue doing a generalist's job, just as they did 30 years ago and earlier. Theirs is hardly a narrow groove, except on rare occasions. (Krishna 2010, p. 435)

It is useful to compare the IAS system to managerial rotation systems used by large corporations. An IAS officer working in finance is not a financier. Her job is to integrate the operations of the finance group with the larger operations and goals of the state, as much as it is to run her department well. This basic pattern of recruiting and cross-training rising stars, in other words, is not unique to the Indian government.

\section{Rising through the ranks}

Most IAS promotions are nearly automatic. Officers receive regular raises and titular promotions based on their tenure. By default, such promotions take place in an officer's assigned cadre. There are two types of postings though that convey exceptional status and greatly increase an officer's prospects of advancing into the highest echelons of the service. It is these postings, known as Centre postings and empanelment, on which we focus.

After their fourth year in the service, officers may begin to compete for posting to a central-government post in New Delhi, known as "the Centre." Officers who are on central posting join ministries' senior staffs and play a larger role in formulating policy (Shurmer-Smith 1998). Only about two thirds of all IAS officers ever receive such a posting in their career. 
Centre postings are voluntary and a few officers prefer never to leave their state-level posts. There is nonetheless little doubt that Centre postings are a goal for most IAS officers: "The greatest attraction lies with appointments within the central government" (Singh \& Srinivasan 2006, p. 315). In our empirical analyses we handle unobserved differences in officers' propensities to bid for Centre postings by estimating individual fixedeffects models.

Empanelment as Joint Secretary in the Central Government is the next milestone. Empanelment is a prerequisite for becoming a Secretary to the Government of India, the highest bureaucratic position in the country. High performance in previous postings is a necessary but by no means sufficient condition for empanelment. An empanelment selection committee is required by statute to evaluate all officers who are eligible for empanelment; that is, there is no self-selection into bidding for these positions.

All of these institutional features guide our identification strategy. First, the IAS itself reduces the variability of officer ability through its rigorous selection system. Second, IAS officers exhibit significant exogenous variation in the accumulation of major experiences, especially at the earlier stages of their career. The variation results more from the idiosyncratic vacancies in the bureaucracy than from their own desire to specialize. Yet IAS officers have common career goals: Centre postings, then empanelment as joint secretaries. A final important feature is that non-retirement exits from the service are extremely rare. Unlike many other labor markets, survivor bias is not a significant issue here. Table 1 compares the total number of "regular recruitment" officers in our data and the total number of IAS officers recruited in that year from 1995 until 2008 (we explain regular recruitment below). More than 96 percent of the officers who were recruited into the IAS since 1980 appear in our data.

[Table 1 about here]

For our purposes, the IAS can be thought of as a system that sifts through the population to identify individuals with comparable, high ability; assigns those individuals careers that vary in the diversity of the constituent experiences; and evaluates those individuals for a common set of rewards. A key feature behind our strategy is that the diversity of an IAS officer's experience can be thought of as exogenously assigned, conditional on other observed characteristics. This maximizes the likelihood that any effects of specialization that we do observe in this labor market come from the mechanisms we theorize rather than from self-selection or survivor bias. Furthermore, the IAS's two comparable career hurdles give us an excellent setting in which to evaluate the relative importance of skill in determining the outcomes of early- and late-career milestones. ${ }^{1}$

\footnotetext{
${ }^{1}$ We recognize that other mechanisms matter for IAS officer's career advancement, chief among them the possibility, at least of political favoritism or corruption. We discuss the likely role of such factors in robustness checks that we describe in the online appendix.
} 


\section{Data and Empirical Approach}

\section{Data}

We assembled data from the administrative records of the 4,259 Indian Administrative Officers who began their careers between 1974 and 2008. Individuals can enter the IAS through two different routes. Regular recruits, comprising seventy three percent of our sample, begin their careers in their mid-to late twenties. The remaining 37 percent entered via promotion from a state civil service. Promotees enter the IAS much later in their career, usually work in one area, and do not become joint secretaries. We therefore excluded promotes from our analysis.

The risk set for posting to New Delhi consists of 3,122 officers who entered through regular recruitment, contributing 420,676 monthly observations. When we model empanelment, we consider only the eligible officers, those who have received a Centre posting (Department of Personnel and Training 2011, p. A1). These 1,220 officers contribute 139,075 post-promotion, pre-empanelment monthly observations.

We want to examine the effects of specialization on clearing early-and late-career milestones, and the match between the skills accumulated and the job attained. We begin our analysis by modeling postings to the Centre and examining matches between early-career experience and the types of work that those posted get in New Delhi. We then model empanelments and examine the match between late-career experience and the jobs that joint secretaries have.

\section{Dependent variables}

Centre posting: We model posting to the Centre as the first transition from a state-level posting to a posting in New Delhi. In our data, we observe 2,083 transitions to the Centre by regular-recruitment officers, for a promotion rate of 66.7 percent.

Empanelment: We examine whether officers promoted to the Centre were later empaneled. We focus on the 1,220 officers who entered the IAS between 1974 and 1989 and were ever promoted to the Centre. (No officer who entered after 1989 had yet been empaneled by 2008.) Of these, 407 were empaneled.

\section{Independent variable}

We observe each officer's complete career history since his or her entry into the IAS. Each posting includes information on whether the officer was employed in the Centre or in the states, their seniority level, the start- and 
end-dates for the posting and the "major experience" that they acquired during the spell. Our main independent variable, the degree of specialization, is calculated using a Herfindahl index. For each individual $i$ in time $t$ we observe the number of months they have previously worked in one of forty experiences $m$. These experiences and the distribution of monthly experience are described in Table 2. First, we calculate the individual's experience at each period. We denote $S_{i m t}$ as the total months an officer $i$ has in experience $m$ in month $t$ of their tenure. The Herfindahl score $H_{i t}$ is then calculated by summing the squared shares of all major experiences through time period for each individual:

$$
H_{i t}=\sum_{m}\left(\frac{s_{i m t}}{s_{i t}}\right)^{2}
$$

Herfindahl indices can range from 0 to 1 ; larger scores imply increased specialization. We postulate that there will be a positive relationship between specialization and posting to New Delhi. To avert any bias introduced by the skewness of the Herfindahl, our estimations use the natural log of the index.

[Table 2 about here.]

By construction, the Herfindahl index tracks both the absolute number of different types of experience as well as the number of months (as a share of the total) spent in each. However, the Herfindahl does not track how many moves between jobs were made in accumulating those shares. Our goal is to interpret the Herfindahl index as pure a measure of non-systematic variation as possible. Accordingly, while we focus on the coefficients estimated for the index, we also include and discuss variables that track the number of moves officers have made, their depth of experience in specific types of work and other elements of the IAS officer's career.

\section{Control variables}

We include a substantial set of controls to account for other sources of heterogeneity among the officers that may affect their first transition into a Centre posting and their empanelment. First, we control for the number of academic degrees that an officer holds, their college major, the count of the different subjects they studied across their various degrees, and their academic performance as indicated graduating in the first division.

To measure experience, we control for an officer's number of prior postings, its square and an officer's tenure in the IAS, in months. To take into account an officer's ability to leverage their in-group membership to increase their chances of a Centre posting, our models include variables indicating whether officers speak Hindi, Bengali, Telugu, Marathi and Tamil - dominant Indian languages. Finally, we also control for officers' age and gender.

In order to control for any unobserved heterogeneity between cohorts, states and years, we include indicators 
for the five-year cohort to which the IAS officers belong (e.g., 1970-1974 or 1985-1989), the cadre to which they have been allocated and the calendar year.

In order to capture the effects of political interference, we gathered data on chief-ministerial turnover and changes in party control in each state from 1970 to 2008 and created an indicator variable for any change in government or party and in the month following the change. Windows up to four months produce comparable results.

We also consider the role that favoritism plays by examining homophily (McPherson, Smith-Lovin \& Cook 2001) in the central government. Specifically, if a ministry in New Delhi already has several staffers from an IAS officer's cadre or several of his fellow cohort-recruits, then that officer might be more likely to be promoted. To test this possibility, we calculated each cadre's and cohort's share of ministerial positions in each month (Barnett, Baron \& Stuart 2000).

Finally, we estimate individual fixed-effect models that account for any time-invariant but unobserved officer characteristics as well as predilections to bid for Centre postings. Summary statistics are presented in Table 3.

[Table 3 about here.]

\section{Results}

\section{Promotion to the Centre}

Table 5 presents the estimated discrete-time event-history models of the first posting to the Centre. In addition to career specialization, we include the control variables described above and cluster standard errors at the officer level. Column 1 includes the number of moves an officer has made, their age and their tenure in the IAS. As expected, both the number of postings and age have an inverted-U shaped relationships to the risk of a Centre posting. Posting probability peaks at age 46. Column 1 also includes specialization, which is positive as expected and significant. The coefficient of 0.942 suggests that between two officers who have the same tenure, are the same age and have had as many distinct jobs in the IAS, the officer whose logged specialization score is one standard deviation above the mean is approximately 36 percent more likely to receive a posting to the Centre in the next time period.

Column 2 introduces three sets of fixed effects. First, cadre effects are included to take into account differences in the size of the state bureaucracy, patterns of association among the state's bureaucrats and so on. Second, cohort effects control for any idiosyncrasies of different cohorts, as one might expect for example if the favored college majors for IAS officers had changed over time or if the incoming quality of IAS applicants has systematically varied. Third, calendar-year effects control for year-specific shocks that may affect promotion 
chances; these include political changes in the central government, the creation or removal of offices in New Delhi and any reforms, such as India's economic liberalization in the 1990s. The estimated effect of specialization is robust to their inclusion. Unless otherwise noted, all following models include these fixed effects.

Column 3 adds basic demographic controls to the model. We find that female IAS officers are more likely to be posted to the Centre as are officers from some of the major linguistic groups. Column 4 introduces controls for human capital. As would be expected, we find strong and positive effects graduating in the first division of one's undergraduate class and having multiple academic degrees.

Column 5 adds controls for political change and favoritism. The number of observations is smaller in this model because, for early entrants to our data set, we have less information about the senior IAS officers in New Delhi when they were at risk for Centre posting. To minimize bias, we estimate this model excluding those officers who entered the IAS in the 1970s. We find no evidence that favoritism by cadre or cohort takes place. If anything, we find evidence of crowding out: having more people from your cadre or cohort already in New Delhi reduces your chances of getting a posting. The coefficient for a new Chief Minister, which tracks exceptional opportunities for political interference, is negative and significant. Immediately after political changes in a state, officers are less likely to be posted to New Delhi. However, it does not significantly alter our coefficient on specialization.

[Table 5 about here.]

The results in table 5 support our prediction that, early in their careers, officers who receive specialized work experience are more likely to be posted to the Centre. In table 6, we show several checks on the robustness of these results. Column 1 of table 6 restricts the risk-set for Centre postings to those officers who have twelve or fewer years of tenure in the IAS in order to estimate our models on a more conservative risk-set. The coefficient on specialization remains significant in this model.

[Table 6 about here.]

Column 2 includes our first test for whether it matters what type of work an IAS officer specialized in, or whether the fact of specialization alone explains Centre postings. Specialization could be favored for a variety of reasons. It could be because the worker has required a specific set of skills that are useful for their future posting. It is also plausible that specialization has improved past work performance, which in turn improves their chances of posting to the central government. Alternatively, specialization could produce better relationships with supervisors or simply give the latter better opportunities to observe the worker's performance. In column 2 we include a set of 39 variables that count, for each officer in each month, the number of months that they have 
worked in each of the IAS's major experiences. If our measure of specialization only reflects preference for those who have acquired specific skills, then including these skill profiles should mediate the effect on specialization. It does not. This result also holds in column 3, where we estimate individual-fixed effects models. Including these fixed effects lets us control for officers' caste, any remaining differences in unobserved ability, and for any variance in their propensity to bid for Centre postings. The effect of specialization still holds.

We further test this idea by estimating multinomial logistic regressions to examine, among those who have received Centre postings, whether there is a match between their accumulated experience and the postings they subsequently received. We hypothesized that there will be no systematic match between amassed experience and next job, early in officers' careers. Table 7 presents these results for the five most common fields of specialization. The most important coefficients, which we have emphasized, are those that show the likelihood of such a match. Thus the way to interpret the coefficients in table 7 are as follows: an officer who specialized in Personnel and who was promoted was no more likely to work in Personnel in the Centre than to work in any other area in the Centre, an officer who specialized in Commerce and who was promoted was less likely to work in Commerce in the Centre than in other areas, and so on. There is no systematic relationship. (Including more fields of specialization does not change the result.) Save for finance, an officer's specializing in a field does not raise the likelihood of their being posted to work in that field in the Centre. Taken together, the results from tables 6 and 7 support our proposition that, early in a career, specialization is not rewarded because of the particular work the officer has done. This leaves open two other mechanisms, which are admittedly difficult to tease apart: that specialization helps evaluators reduce their uncertainty about an officer's ability, or that specialization gives an officer a better chance to develop positive working relations with their supervisor, and thus receive stronger evaluations.

[Table 7 about here.]

\section{Empanelment as Joint Secretary}

The second analysis we conduct examines whether an officer who has been promoted to the Centre is eventually empaneled as a joint secretary. As in the first stage, we estimate discrete-time event-history models of empanelment. The estimated models, presented in Table 8 , include the same controls as the models for first promotion to the Centre.

[Table 8 about here]

Column 1 presents the control variables. The results are similar to those for the Centre posting analysis. We 
find inverted-U shaped relationships between the number of postings, age and the probability of empanelment. Save for Hindi-language speakers, the ascriptive variables have no significant effect on the probability of empanelment. Officers who graduated from college in the first division are 66 percent more likely to be empaneled than others. We also find some effect of having a larger number of degrees, but the effects are not as large as having graduated in the first division. Even with these controls, we find that an officer with a level of specialization one standard deviation above the mean for those in the risk set is 43 percent more likely to be empaneled.

One reservation about the results in column 1 is that, while we observe multiple measures of human capital and work experience, we cannot observe more job-and organization-specific measures of individual potential and fit with the organization (Jovanovic 1979, Jovanovic 1984). Officers may be promoted to Delhi because they are expected to do well there, and more importantly may not be promoted when their superiors think that their prospects for further career advancement are poor. One way to model this potential endogeneity is to include for each individual who was promoted their predicted probability of promotion from the first-stage model. The logic behind this is straightforward: someone who is posted to New Delhi because they have potential that our firststage model does not capture will have a large residual in that first stage, and thus a low predicted probability of promotion. More "typical" candidates will have a higher predicted probability and a smaller residual, because they have less exceptional potential net of observables. Predicted probability of a Centre posting should thus be negatively correlated with empanelment. Our estimation in column 2 includes this predicted probability. It is indeed negatively and significantly correlated with empanelment. However, including it does not significantly alter specialization's effect.

Since the state governments in India do have sway with the central government, it is reasonable to suspect that government changes in states can affect appointments of administrative officers in the capital. In column 3 we therefore include our control for whether the chief minister of the state in which the IAS officer has worked has changed. Its effect is small and not significant.

In column 4, we show the first test of our prediction that later in careers specialization will be rewarded because workers have differentiated themselves in terms of their accumulated specific skills. As in column 6 of table 6, we include a vector of months spent working in each type of IAS posting. In table 2, specialization remained significant after adding these controls. Here, though, their inclusion reduces the estimated effect of specialization by more than half, and it is no longer significant. For joint secretaries, then, we can explain most of the preference for specialists in terms of the specific jobs they have done in the past.

Table 9 elaborates on this point. As with table 7, here we estimate a multinomial logistic regression showing, among those who were empaneled, the relationship between their accumulated experience and the job they subsequently received. Our theory predicts that there will be a systematic match between amassed experience and the next job at this late-career stage. Here we show the top four fields, which together account for about 40 
percent of all empanelments (Results with more fields are similar). In this model, the relevant coefficients, which are emphasized, are significant and positive. Taken together, the results from table 8 and 9 support our proposition that, late in a career, more specialization is rewarded because it reflects specific skills.

[Table 9 about here]

We tried several different specifications of the empanelment models. A common reservation about the use of Herfindahl indices in dynamic models is that any such time-varying index can be correlated with time, which can bias estimates of time-varying effects (Allison \& Christakis 2006). One way to break this correlation is to dispense with the event-history framework and instead use a simpler specification of time. Dispensing with the framework means being unable to estimate the effects of individual variables that vary in time, such as tenure and number of promotions. It is however worth checking that doing so does not come at the cost of the abovementioned bias. We therefore estimated simple logit models of whether an officer who was posted to New Delhi was ever empaneled in the ten-year period following their promotion. In these models we included a snapshot of their post-Centre specialization, operationalized as their specialization score five years after their posting. No officers were empaneled in fewer than five years after their first Centre posting, so this seemed a reasonable window to use. These models yielded substantively similar results to our main models, as do event-history ones that use slightly different time windows for the snapshot of specialization and empanelment. Models that use a snapshot of early-career specialization after four years (when officers are first eligible for posting to New Delhi) and that ask whether an officer was ever posted to New Delhi in their first ten years in the service also yield results that are comparable to our first-stage analysis. We are confident therefore that the event-history models are appropriate for analyzing these data.

\section{Robustness checks}

We also conducted several robustness checks to examine other factors that may potentially bias our results. First, we examined whether different types of work have different status, and whether job status affects an officer's level of specialization. Our analysis suggested that while different types of work had different levels of status, there was little evidence that status correlated with the level of specialization. Similarly, we did not find evidence that there were distinct "tracks" in IAS careers. Finally, we examined whether specializing in "rare" types of work, whether of high or low status, affected our results. We find that gaining rarer types of experience increases an officer's chance of promotion $(\beta=1.184, \sigma=.074)$, but does not significantly alter the effect of specialization in our key models $(\beta=1.569, \sigma=.116)$, which remains both positive and statistically significant. A fuller account of these robustness checks is presented in an online appendix. 


\section{Discussion}

Our results support the contention that both skill- and signaling-based mechanisms are at play in relating specialization to career advancement. We argue that signaling matters, especially early in an IAS officer's career; but signaling also produces a self-fulfilling prophecy, wherein people who specialize acquire skills and thus have incentives to continue specializing. These effects are strong and persist even when we control for other characteristics of individuals and their careers, such as their education, favoritism, the status and type of work they have performed and their ascriptive qualities, as well as individual fixed effects. Furthermore the nature of IAS job mobility rules out self-selection as a mechanism that would produce differences in specialization. These results are all the more striking given that the IAS's internal labor market is explicitly committed to producing general managers. This suggests that we would find even stronger effects in other labor markets, and accordingly even stronger incentives toward and rewards for specializing.

This study has shown that a diverse work history hurts one's chances of promotion; prior work has also shown that such work histories imply lower wages (Acemoglu \& Pischke 1999b), greater risks of termination (Osterman \& Burton 2004), and less professional recognition (Leahey 2007). Finding differential returns from specialization in this environment, where self-selection is not a serious issue, should make us hesitate before attributing such effects to self-selection elsewhere. Scholars of stratification and inequality in organizations should be alert to structures beyond individual workers' control that can increase their movement between different types of work. Such structures might include the vagaries of project-based jobs and temporary work, but also larger social structures like racial and sexual discrimination, which historically restricted blacks and women to more casual jobs within various industries and made it hard for them to construct careers within a single industry (Piore 1973, Milkman 1987). Such structures could indirectly increase inequality through the mechanism of specialization.

This study has two limitations, both of which suggest directions for future research. First, while we have been able to rule out specific skills as the mechanism linking specialization to promotion early in IAS officers' careers, it is harder for us to judge between several other mechanisms that could produce the effect. Here we emphasize the signaling and typecasting role that career histories play. However, it is also possible that specializing in one type of work lets an officer develop better relations with their superiors and supervisors, and thus at any level of actual performance more specialized officers will receive higher evaluations of their performance (Castilla 2008). We stress though that this study focuses on specialization in a type of work, not in a specific job. More specialized IAS officers do not necessarily have longer relationships with a single supervisor than less specialized officers. Second, and related to this point, while we have multiple controls for differences in ability, we do not have information on individuals' performance in specific jobs. This would seem to be the ideal data to test whether specialization in a single type of work actually improves performance. Even if we had performance evaluations, 
though, we could not evaluate the between-individual, within-job effects of specialization, precisely because we do not directly observe the strength of personal relationships. This individual-relations mechanism, it should be noted, does not invalidate signaling as a possible mechanism. It implies that the signal inheres in the performance evaluations rather than the career history in and of itself. Second, we do not observe the bidding pool for each vacancy. We can partially control for whether officers put themselves up for posting to the Centre at different rates, via the individual fixed-effects models; but we cannot know whether for example different ministries value specialization differently, without seeing all the candidates they considered for each opening. We can say though that this is unlikely to apply at the empanelment stage, where all officers in a cohort are simultaneously evaluated; and we have no theoretical prior for expecting self-selection on this dimension into the bidding pool at the earlier stage. Ideally future research into such effects of specialization on career paths will leverage empirical settings where data on supply-side sorting is available, as for example has been done in the work on networks and hiring (Fernandez \& Mors 2008, Fernandez \& Friedrich 2011).

\section{References}

Acemoglu, Daron \& Jörn-Steffen Pischke. 1999a. "Beyond Becker: Training in Imperfect Labour Markets." The Economic Journal 109:F112-F142.

Acemoglu, Daron \& Jörn -Steffen Pischke. 1999b. "The Structure of Wages and Investment in General Training." Journal of Political Economy 107(3):539-572.

Allison, P. D. \& N. Christakis. 2006. "Fixed Effects Methods for the Analysis of Non Repeated Events." Sociological Methodology 36(1):155-172.

Arthur, Michael B. \& Denise M. Rousseau, eds. 1996. The boundaryless career: A new employment principle for a new organizational era. Oxford University Press.

Autor, David H. 2001. "Why do temporary help firms provide free general skills training?" Quarterly Journal of Economics 116(4):1409-1448.

Barnett, William P., James N. Baron \& Toby E. Stuart. 2000. “Avenues of Attainment: Occupational Demography and Organizational Careers in the California Service 1.” American Journal of Sociology 106(1):88-144.

Becker, Gary S. 1962. "Investment in human capital: a theoretical analysis." The Journal of Political Economy 70(5):9-49.

Bidwell, Matthew \& Isabel Fernandez-Mateo. 2010. "Relationship Duration and Returns to Brokerage in the Staffing Sector.” Organization Science pp. 1-18.

Booth, Alison L., Marco Francesconi \& Jeff Frank. 2002. “Temporary Jobs: Stepping Stones or Dead Ends?" The Economic Journal 112:F189-F213. 
Borland, Jeff. 2006. "Career Concerns: Incentives and Endogenous Learning in Labour Markets." Journal of Economic Surveys 6(3):251-270.

Cappelli, Peter. 1999. The New Deal at Work: Managing the Market-Driven Workforce. Boston: Harvard Business School Press.

Castilla, Emilio J. 2008. "Gender, Race, and Meritocracy in Organizational Careers.” American Journal of Sociology 113(6):1479-1526.

Department of Personnel and Training. 2011. Retention of Names on Offer for Central Deputation Under the Central Staffing Scheme for the Year 2011. Technical report Government of India.

Doeringer, Peter and Michael J. Piore. 1971. Internal Labor Markets and Manpower Analysis. Lexington, MA: Heath.

Fernandez, Roberto M. \& Collete Friedrich. 2011. “Gender Sorting at the Application Interface.” In press.

Fernandez, Roberto M. \& Marie Louise Mors. 2008. "Competing for jobs: Labor queues and gender sorting in the hiring process." Social Science Research 37:1061-1080.

Gargan, Edward A. 1993. "New Delhi Journal; A Students' Prayer: Let Me Join the Ruling Class." URL: http://query.nytimes.com/gst/fullpage.html?res=9F0CEFD9113DF935A35751C1A965958260

Hsu, Greta. 2006. "Jacks of all trades and masters of none: Audiences' reactions to spanning genres in feature film production.” Administrative Science Quarterly 51(3):420-450."

Ishida, Junichiro. 2004. "Signaling and strategically delayed promotion." Labour Economics 11(6): 687-700.

Ishida, Junichiro. 2006. “Optimal Promotion Policies with the Looking-Glass Effect.” Journal of Labor Economics 24(4):857-877.

Jayapalan, N. 2001. Indian Administration. Atlantic Publishers and Distributors.

Jovanovic, Boyan. 1979. "Job matching and the theory of turnover." The Journal of Political Economy 87(5):972990.

Jovanovic, Boyan. 1984. "Matching, turnover, and unemployment." The Journal of Political Economy 92(1):108122.

Krishna, Anirudh. 2010. "Continuity and change: the Indian administrative service 30 years ago and today." Commonwealth \& Comparative Politics 48(4):433-444.

Leahey, Erin. 2007. "Not by Productivity Alone: How Visibility and Specialization Contribute to Academic Earnings.” American Sociological Review 72(4):533-561.

McPherson, Miller, Lynn Smith-Lovin \& James M. Cook. 2001. "Birds of a Feather: Homophily in Social Networks." Annual Review of Sociology 27:415-444.

Milkman, Ruth. 1987. Gender at Work: The Dynamics of Job Segregation by Sex during World War II. Champaign, IL: University of Illinois Press. chs. 1, 4, and 7, pp. 1-11, 49-64, and 99-127. 
Mincer, Jacob \& Boyan Jovanovic. 1981. Labor Mobility and Wages. In Studies in Labor Markets, ed. Sherwin Rosen. University of California Press pp. 21-64.

Neal, Derek. 1998. "The Link between Ability and Specialization: An Explanation for Observed Correlations between Wages and Mobility Rates.” The Journal of Human Resources 33(1):173-200.

Osterman, Paul \& M. Diane Burton. 2004. Ports and Ladders: The Nature and Relevance of Internal Labor Markets in a Changing World. In The Oxford Handbook on Work and Organization, ed. Pamela Tolbert \& Rosemary Batt. Oxford: Oxford University Press.

Parsons, Donald O. 1972. "Specific Human Capital: An Application to Quit Rates and Layoff Rates." Journal of Political Economy 80:1120-1143.

Piore, Michael J. 1973. Notes for a theory of labor market stratification. In Labor market segmentation, ed. Richard C. Edwards, Michael Reich \& David M. Gordon. Lexington, MA: D.C. Heath and Company pp. $125-150$.

Potter, David C. 1986. India's political administrators, 1919-1983. Clarendon Press.

Rosen, Sherwin. 1972. "Learning and Experience in the Labor Market." Journal of Human Resources 7(3):327342.

Rosen, Sherwin. 1983. “Specialization and Human Capital.” Journal of Labor Economics 1(1):43-49.

Shurmer-Smith, Pamela. 1998. "Becoming a Memsahib: Working with the Indian Administrative Service." Environment and Planning A 30:2163-2180.

Simmons, Rob and David J. Berri. "Gains from Specialization and Free Agency: The Story from the Gridiron." Review of Industrial Organization 34(1):81-98.

Singh, Nirvikar \& T. N. Srinivasan. 2006. Indian Federalism, Economic Reform and Globalization. In Federalism and Economic Reform, ed. T. N. Srinivasan \& Jessica Seddon Wallack. Cambridge University Press pp. 301363.

Spence, Michael. 1973. “Job Market Signaling.” The Quarterly Journal of Economics 87(3):355-374.

Ward, Kevin, Damian Grimshaw, Jill Rubery \& Huw Beynon. 2001. "Dilemmas in the Management of Temporary Work Agency Staff.” Human Resource Management Journal 11(4):3-21.

Wholey, Douglas R. 1985. "Determinants of Firm Internal Labor Markets in Large Law Firms.” Administrative Science Quarterly 30:318-335.

Zuckerman, Ezra W. 1999. "The categorical imperative: Securities analysts and the illegitimacy discount." American Journal of Sociology 104(5):1398-1438.

Zuckerman, Ezra W. 2000. "Focusing the Corporate Product: Securities Analysts and De-Diversification." Administrative Science Quarterly 45:591-619.

Zuckerman, Ezra W. 2005. "Typecasting and Generalism in Firm and Market: Genre-Based Concentration in the Feature Film Industry, 1933 - 1995.” Research in the Sociology of Organizations 23:173-216. 
Zuckerman, Ezra W., Tai-Young Kim, Kalinda Ukanwa \& James von Rittman. 2003. "Robust Identities or NonEntities? Typecasting in the Feature-Film Labor Market.” American Journal of Sociology 108(5):1018-1074. 


\section{Tables}

Table 1: Comparison of IAS officers admitted (from Indian Personnel Ministry Annual Reports, 1995-2008) to IAS officers in data set

\begin{tabular}{cccc}
\hline \hline Allotment Year & Actual Admitted & In data & Difference \\
\hline 1995 & 80 & 79 & 1 \\
1996 & 80 & 78 & 2 \\
1997 & 76 & 76 & 0 \\
1998 & 55 & 55 & 0 \\
1999 & 55 & 51 & 4 \\
2000 & 56 & 55 & 1 \\
2001 & 59 & 58 & 1 \\
2002 & 59 & 59 & 0 \\
2003 & 70 & 70 & 0 \\
2004 & 89 & 88 & $1^{(1)}$ \\
2005 & 91 & 90 & 1 \\
2006 & 87 & 86 & 1 \\
2007 & 89 & 89 & 0 \\
2008 & 111 & 109 & $2^{(2)}$ \\
\hline Total & 1057 & 1044 & 15 \\
\hline
\end{tabular}

1. One person transferred to the Indian Foreign Service after entry.

2. The initial allocation of two candidates was provisional, and neither was ultimately cleared. 
Table 2: Distribution of monthly experience by type for IAS officers 1974-2008

\begin{tabular}{|c|c|c|c|}
\hline Experience & Frequency & Percent & Cumulative \\
\hline Land Revenue Mgmt and District Admn & 230314 & 38.38 & 38.38 \\
\hline Personnel and General Admn & 46060 & 7.67 & 46.05 \\
\hline Finance & 42840 & 7.14 & 53.19 \\
\hline Industries & 32878 & 5.48 & 58.66 \\
\hline Agriculture and Cooperation & 27136 & 4.52 & 63.19 \\
\hline Urban Development & 24282 & 4.05 & 67.23 \\
\hline Human Resource Dev & 18279 & 3.05 & 70.28 \\
\hline Rural Dev & 16623 & 2.77 & 73.05 \\
\hline Social Justice and Empowerment & 15086 & 2.51 & 75.56 \\
\hline Home & 14294 & 2.38 & 77.94 \\
\hline Health and Family Welfare & 12246 & 2.04 & 79.98 \\
\hline Energy & 10915 & 1.82 & 81.8 \\
\hline Consumer Affairs, Food and PD & 10757 & 1.79 & 83.59 \\
\hline Commerce & 9941 & 1.66 & 85.25 \\
\hline Transport & 9322 & 1.55 & 86.8 \\
\hline Planning and Prog Implementation & 7365 & 1.23 & 88.03 \\
\hline Textiles & 6401 & 1.07 & 89.1 \\
\hline Water Resources & 6005 & 1 & 90.1 \\
\hline Tourism & 5359 & 0.89 & 90.99 \\
\hline Labour and Employment & 5095 & 0.85 & 91.84 \\
\hline Local Self Govt & 5091 & 0.85 & 92.69 \\
\hline Environment and Forests & 5074 & 0.85 & 93.53 \\
\hline Law and Justice & 4848 & 0.81 & 94.34 \\
\hline Women and Child Dev & 4446 & 0.74 & 95.08 \\
\hline Information and Broadcasting & 3992 & 0.67 & 95.75 \\
\hline Communications and Information Technology & 3459 & 0.58 & 96.32 \\
\hline Mines and Minerals & 3411 & 0.57 & 96.89 \\
\hline Defence & 3404 & 0.57 & 97.46 \\
\hline Culture & 3168 & 0.53 & 97.99 \\
\hline Science and Technology & 2892 & 0.48 & 98.47 \\
\hline Youth Affairs and Sports & 2572 & 0.43 & 98.9 \\
\hline Public Works & 2388 & 0.4 & 99.29 \\
\hline Petroleum and Natural Gas & 1581 & 0.26 & 99.56 \\
\hline Staff Officers & 1150 & 0.19 & 99.75 \\
\hline Chemicals and Fertilizers & 569 & 0.09 & 99.84 \\
\hline Parliamentary Affairs & 467 & 0.08 & 99.92 \\
\hline External Affairs & 241 & 0.04 & 99.96 \\
\hline Corporate Management & 193 & 0.03 & 99.99 \\
\hline Development of NER & 35 & 0.01 & 100 \\
\hline
\end{tabular}


Table 3: Summary statistics: First posting to central government analysis

\begin{tabular}{lccc}
\hline \hline & count & mean & sd \\
\hline Promotion to Centre & 428439 & 0.003 & 0.06 \\
Postings & 428439 & 4.084 & 4.26 \\
Age & 428439 & 34.500 & 6.88 \\
Female & 428439 & 0.134 & 0.34 \\
Hindi & 428439 & 0.521 & 0.50 \\
Bengali & 428439 & 0.036 & 0.19 \\
Telugu & 428439 & 0.070 & 0.26 \\
Marathi & 428439 & 0.033 & 0.18 \\
Tamil & 428439 & 0.075 & 0.26 \\
First Division & 428439 & 0.667 & 0.47 \\
Engineering & 428439 & 0.230 & 0.42 \\
Humanities & 428439 & 0.317 & 0.47 \\
Medicine & 428439 & 0.045 & 0.21 \\
Professional & 428439 & 0.141 & 0.35 \\
Science & 428439 & 0.321 & 0.47 \\
Business & 428439 & 0.186 & 0.39 \\
Law & 428439 & 0.077 & 0.27 \\
No. of Subjects & 428439 & 1.710 & 0.84 \\
Two degrees & 428439 & 0.435 & 0.50 \\
Three degrees & 428439 & 0.192 & 0.39 \\
Four degrees & 428439 & 0.092 & 0.29 \\
Cadre share in Centre & 312365 & 0.017 & 0.11 \\
Cohort share in Centre & 316838 & 0.017 & 0.11 \\
New Chief Minister & 428439 & 0.068 & 0.25 \\
Specialization & 428439 & -1.688 & 0.53 \\
\hline Observations & 428439 & & \\
\hline \hline
\end{tabular}


Table 4: Summary statistics: Empanelment to Joint Secretary analysis

\begin{tabular}{lccc}
\hline \hline & count & mean & sd \\
\hline Promotion to Centre & 164434 & 0.004 & 0.06 \\
Postings & 164434 & 8.583 & 4.08 \\
Age & 164434 & 41.960 & 5.87 \\
Female & 164434 & 0.147 & 0.35 \\
Hindi & 164434 & 0.485 & 0.50 \\
Bengali & 164434 & 0.070 & 0.26 \\
Telugu & 164434 & 0.055 & 0.23 \\
Marathi & 164434 & 0.025 & 0.16 \\
Tamil & 164434 & 0.089 & 0.29 \\
First Division & 164434 & 0.626 & 0.48 \\
Engineering & 164434 & 0.147 & 0.35 \\
Humanities & 164434 & 0.401 & 0.49 \\
Medicine & 164434 & 0.016 & 0.13 \\
Professional & 164434 & 0.216 & 0.41 \\
Science & 164434 & 0.366 & 0.48 \\
Business & 164434 & 0.226 & 0.42 \\
Law & 164434 & 0.082 & 0.27 \\
No. of Subjects & 164434 & 1.922 & 0.87 \\
Two degrees & 164434 & 0.424 & 0.49 \\
Three degrees & 164434 & 0.274 & 0.45 \\
Four degrees & 164434 & 0.161 & 0.37 \\
Specialization & 164434 & -1.700 & 0.30 \\
\hline Observations & 164434 & & \\
\hline \hline
\end{tabular}


Table 5: Logistic Regressions of First Posting to Central Government

\begin{tabular}{|c|c|c|c|c|c|}
\hline & $(1)$ & $(2)$ & $(3)$ & $(4)$ & $(5)$ \\
\hline \multicolumn{6}{|l|}{ Promotion to Centre } \\
\hline Postings & $\begin{array}{l}0.513^{* * *} \\
(0.0353)\end{array}$ & $\begin{array}{c}0.570^{* * *} \\
(0.0368)\end{array}$ & $\begin{array}{l}0.580^{* * *} \\
(0.0370)\end{array}$ & $\begin{array}{l}0.572^{* * *} \\
(0.0374)\end{array}$ & $\begin{array}{l}0.547^{* * *} \\
(0.0374)\end{array}$ \\
\hline$(\text { Postings })^{2}$ & $\begin{array}{c}-0.0174^{* * *} \\
(0.00216)\end{array}$ & $-0.0171^{* * *}$ & $-0.0173^{* * *}$ & $\begin{array}{c}-0.0171^{* * *} \\
(0.00213)\end{array}$ & $-0.0153^{* * *}$ \\
\hline Age & $\begin{array}{l}0.555^{* * *} \\
(0.0730)\end{array}$ & $\begin{array}{l}0.803^{* * *} \\
(0.0859)\end{array}$ & $\begin{array}{l}0.801^{* * *} \\
(0.0862)\end{array}$ & $\begin{array}{l}0.820^{* * *} \\
(0.0867)\end{array}$ & $\begin{array}{l}0.715^{* * *} \\
(0.0865)\end{array}$ \\
\hline$(\text { Age })^{2}$ & $\begin{array}{r}-0.00603^{* * *} \\
(0.000959)\end{array}$ & $\begin{array}{c}-0.00853^{* * *} \\
(0.00112)\end{array}$ & $\begin{array}{c}-0.00827^{* * *} \\
(0.00112)\end{array}$ & $\begin{array}{c}-0.00821^{* * *} \\
(0.00112)\end{array}$ & $\begin{array}{r}-0.00702^{* * *} \\
(0.00111)\end{array}$ \\
\hline IAS Tenure & $\begin{array}{c}-0.0157^{* * *} \\
(0.00119)\end{array}$ & $\begin{array}{c}-0.0171^{* * *} \\
(0.00215)\end{array}$ & $\begin{array}{c}-0.0172^{* * *} \\
(0.00220)\end{array}$ & $\begin{array}{c}-0.0185^{* * *} \\
(0.00221)\end{array}$ & $\begin{array}{c}-0.0196^{* * *} \\
(0.00222)\end{array}$ \\
\hline Specialization & $\begin{array}{l}0.942^{* * *} \\
(0.0908)\end{array}$ & $\begin{array}{c}1.179^{* * *} \\
(0.106)\end{array}$ & $\begin{array}{c}1.286^{* * *} \\
(0.109)\end{array}$ & $\begin{array}{c}1.301^{* * *} \\
(0.110)\end{array}$ & $\begin{array}{c}1.491^{* * *} \\
(0.115)\end{array}$ \\
\hline Female & & & $\begin{array}{c}0.410^{* * * *} \\
(0.101)\end{array}$ & $\begin{array}{c}0.435^{* * *} \\
(0.106)\end{array}$ & $\begin{array}{c}0.352^{* * *} \\
(0.107)\end{array}$ \\
\hline Hindi & & & $\begin{array}{l}0.579^{* * *} \\
(0.0931)\end{array}$ & $\begin{array}{l}0.551^{* * *} \\
(0.0936)\end{array}$ & $\begin{array}{l}0.543^{* * *} \\
(0.0947)\end{array}$ \\
\hline Bengali & & & $\begin{array}{c}0.578^{* * *} \\
(0.173)\end{array}$ & $\begin{array}{c}0.548^{* *} \\
(0.170)\end{array}$ & $\begin{array}{c}0.498^{* *} \\
(0.179)\end{array}$ \\
\hline Telugu & & & $\begin{array}{c}0.222 \\
(0.150)\end{array}$ & $\begin{array}{c}0.169 \\
(0.150)\end{array}$ & $\begin{array}{c}0.130 \\
(0.150)\end{array}$ \\
\hline Marathi & & & $\begin{array}{l}0.0449 \\
(0.238)\end{array}$ & $\begin{array}{l}0.0716 \\
(0.244)\end{array}$ & $\begin{array}{c}0.00221 \\
(0.260)\end{array}$ \\
\hline Tamil & & & $\begin{array}{c}0.502^{* * *} \\
(0.142)\end{array}$ & $\begin{array}{c}0.480^{* * *} \\
(0.145)\end{array}$ & $\begin{array}{c}0.468^{* *} \\
(0.148)\end{array}$ \\
\hline First Division & & & & $\begin{array}{l}0.278^{* * *} \\
(0.0765)\end{array}$ & $\begin{array}{l}0.254^{* * *} \\
(0.0767)\end{array}$ \\
\hline Engineering & & & & $\begin{array}{c}-0.0179 \\
(0.112)\end{array}$ & $\begin{array}{c}-0.0236 \\
(0.113)\end{array}$ \\
\hline Humanities & & & & $\begin{array}{l}-0.227 \\
(0.119)\end{array}$ & $\begin{array}{l}-0.224 \\
(0.120)\end{array}$ \\
\hline Medicine & & & & $\begin{array}{c}-0.665^{* *} \\
(0.209)\end{array}$ & $\begin{array}{c}-0.685^{* *} \\
(0.208)\end{array}$ \\
\hline Professional & & & & $\begin{array}{c}0.172 \\
(0.119)\end{array}$ & $\begin{array}{c}0.180 \\
(0.121)\end{array}$ \\
\hline Science & & & & $\begin{array}{c}-0.279^{* *} \\
(0.0958)\end{array}$ & $\begin{array}{c}-0.262^{* *} \\
(0.0965)\end{array}$ \\
\hline Business & & & & $\begin{array}{l}0.0712 \\
(0.105)\end{array}$ & $\begin{array}{l}0.0411 \\
(0.106)\end{array}$ \\
\hline Law & & & & $\begin{array}{c}-0.323^{*} \\
(0.141)\end{array}$ & $\begin{array}{c}-0.376^{* *} \\
(0.143)\end{array}$ \\
\hline No. of Subjects & & & & $\begin{array}{c}0.118 \\
(0.0821)\end{array}$ & $\begin{array}{c}0.135 \\
(0.0833)\end{array}$ \\
\hline
\end{tabular}


Two degrees

Three degrees

Four degrees

Cadre share in Centre

Cohort share in Centre
0.134

(0.106)

0.257

$(0.133)$

0.319

$(0.172)$

(0.106)

0.223

(0.133)

0.315

(0.170)

$-0.460$

$(0.363)$

$-0.895^{* *}$

(0.277)

$-0.297^{*}$

(0.126)

\begin{tabular}{lccccc} 
Cadre F.E.s & $\mathrm{N}$ & $\mathrm{Y}$ & $\mathrm{Y}$ & $\mathrm{Y}$ & $\mathrm{Y}$ \\
Cohort F.E.s & $\mathrm{N}$ & $\mathrm{Y}$ & $\mathrm{Y}$ & $\mathrm{Y}$ & $\mathrm{Y}$ \\
Year F.E.s & $\mathrm{N}$ & $\mathrm{Y}$ & $\mathrm{Y}$ & $\mathrm{Y}$ & $\mathrm{Y}$ \\
\hline Observations & 434438 & 423672 & 420676 & 420676 & 308570 \\
ll & -8534.3 & -8196.9 & -8100.2 & -8047.3 & -7571.2 \\
\hline \hline
\end{tabular}

Standard errors in parentheses

${ }^{*} p<0.05,{ }^{* *} p<0.01,{ }^{* * *} p<0.001$ 
Table 6: Logistic Regressions of First Posting to Central Government, II

\begin{tabular}{|c|c|c|c|}
\hline & (1) & $(2)$ & $(3)$ \\
\hline \multicolumn{4}{|l|}{ Promotion to Centre } \\
\hline \multirow[t]{2}{*}{ Postings } & $0.785^{* * *}$ & $0.527^{* * *}$ & $0.568^{* * *}$ \\
\hline & $(0.0708)$ & $(0.0370)$ & $(0.0399)$ \\
\hline \multirow[t]{2}{*}{$(\text { Postings })^{2}$} & $-0.0344^{* * *}$ & $-0.0141^{* * *}$ & $-0.0156^{* * *}$ \\
\hline & $(0.00616)$ & $(0.00200)$ & $(0.00216)$ \\
\hline \multirow[t]{2}{*}{ Age } & $1.502^{* * *}$ & $0.684^{* * *}$ & $0.658^{* * *}$ \\
\hline & $(0.231)$ & $(0.0874)$ & $(0.0885)$ \\
\hline \multirow[t]{2}{*}{$(\text { Age })^{2}$} & $-0.0184^{* * *}$ & $-0.00667^{* * *}$ & $-0.00627^{* * *}$ \\
\hline & $(0.00322)$ & $(0.00112)$ & $(0.00114)$ \\
\hline \multirow[t]{2}{*}{ IAS Tenure } & $-0.0180^{* * *}$ & $-0.0199^{* * *}$ & $-0.0146^{* * *}$ \\
\hline & $(0.00315)$ & $(0.00228)$ & $(0.00326)$ \\
\hline \multirow[t]{2}{*}{ Specialization } & $1.721^{* * *}$ & $1.566^{* * *}$ & $2.197^{* * *}$ \\
\hline & $(0.156)$ & $(0.116)$ & $(0.186)$ \\
\hline \multirow[t]{2}{*}{ Female } & $0.335^{* *}$ & $0.322^{* *}$ & $0.289^{*}$ \\
\hline & $(0.127)$ & $(0.109)$ & $(0.112)$ \\
\hline \multirow[t]{2}{*}{ Hindi } & $0.550^{* * *}$ & $0.570^{* * *}$ & $0.578^{* * *}$ \\
\hline & $(0.117)$ & $(0.0975)$ & $(0.0985)$ \\
\hline \multirow[t]{2}{*}{ Bengali } & $0.733^{* * *}$ & $0.550^{* *}$ & $0.618^{* * *}$ \\
\hline & $(0.211)$ & $(0.177)$ & $(0.172)$ \\
\hline \multirow[t]{2}{*}{ Telugu } & 0.00324 & 0.141 & 0.0870 \\
\hline & $(0.199)$ & $(0.156)$ & $(0.163)$ \\
\hline \multirow[t]{2}{*}{ Marathi } & 0.146 & -0.0221 & -0.0598 \\
\hline & $(0.319)$ & $(0.260)$ & $(0.268)$ \\
\hline \multirow[t]{2}{*}{ Tamil } & $0.509^{* *}$ & $0.490^{* *}$ & $0.457^{* *}$ \\
\hline & $(0.166)$ & $(0.153)$ & $(0.152)$ \\
\hline \multirow[t]{2}{*}{ First Division } & 0.107 & $0.254^{* *}$ & $0.239^{* *}$ \\
\hline & $(0.0929)$ & $(0.0781)$ & $(0.0790)$ \\
\hline \multirow[t]{2}{*}{ Engineering } & -0.0783 & -0.0615 & -0.0424 \\
\hline & $(0.135)$ & $(0.113)$ & $(0.116)$ \\
\hline \multirow[t]{2}{*}{ Humanities } & -0.209 & $-0.266^{*}$ & -0.237 \\
\hline & $(0.146)$ & $(0.122)$ & $(0.122)$ \\
\hline \multirow[t]{2}{*}{ Medicine } & $-0.824^{* *}$ & $-0.756^{* * *}$ & $-0.689^{* *}$ \\
\hline & $(0.264)$ & $(0.221)$ & $(0.219)$ \\
\hline \multirow[t]{2}{*}{ Professional } & 0.150 & 0.138 & 0.183 \\
\hline & $(0.150)$ & $(0.123)$ & $(0.122)$ \\
\hline \multirow[t]{2}{*}{ Science } & -0.208 & $-0.299^{* *}$ & $-0.273^{* *}$ \\
\hline & $(0.116)$ & $(0.0991)$ & $(0.0996)$ \\
\hline \multirow[t]{2}{*}{ Business } & 0.0222 & 0.00722 & 0.00235 \\
\hline & $(0.129)$ & $(0.108)$ & $(0.109)$ \\
\hline \multirow[t]{2}{*}{ Law } & $-0.448^{*}$ & $-0.415^{* *}$ & $-0.382^{* *}$ \\
\hline & $(0.184)$ & $(0.145)$ & $(0.147)$ \\
\hline \multirow[t]{2}{*}{ No. of Subjects } & 0.140 & $0.186^{*}$ & $0.177^{*}$ \\
\hline & $(0.103)$ & $(0.0837)$ & $(0.0840)$ \\
\hline
\end{tabular}




\begin{tabular}{lccc}
\hline Two degrees & 0.0240 & 0.100 & 0.134 \\
& $(0.125)$ & $(0.105)$ & $(0.107)$ \\
Three degrees & 0.0551 & 0.206 & 0.206 \\
& $(0.160)$ & $(0.133)$ & $(0.136)$ \\
Four degrees & 0.222 & 0.232 & 0.264 \\
& $(0.208)$ & $(0.172)$ & $(0.174)$ \\
Cadre share in Centre & -0.820 & -0.648 & -0.675 \\
& $(0.489)$ & $(0.383)$ & $(0.396)$ \\
Cohort share in Centre & $-0.881^{* *}$ & $-1.153^{* * *}$ & $-1.111^{* * *}$ \\
& $(0.304)$ & $(0.295)$ & $(0.292)$ \\
New Chief Minister & $-0.443^{* *}$ & $-0.298^{*}$ & $-0.296^{*}$ \\
& $(0.166)$ & $(0.126)$ & $(0.126)$ \\
Depth of Experience & $\mathrm{N}$ & $\mathrm{Y}$ & $\mathrm{Y}$ \\
Individual F.E.s & $\mathrm{N}$ & $\mathrm{N}$ & $\mathrm{Y}$ \\
Cadre F.E.s & $\mathrm{Y}$ & $\mathrm{Y}$ & $\mathrm{N}$ \\
Cohort F.E.s & $\mathrm{Y}$ & $\mathrm{Y}$ & $\mathrm{N}$ \\
Year F.E.s & $\mathrm{Y}$ & $\mathrm{Y}$ & $\mathrm{Y}$ \\
\hline Observations & 209042 & 308570 & 308551 \\
ll & -4683.9 & -7400.0 & -7325.8 \\
\hline \hline Standard errors in parentheses \\
${ }^{*} p<0.05,{ }^{* *} p<0.01,{ }^{* * *} p<0.001$ & & \\
& & & \\
& & &
\end{tabular}


Table 7: Multinomial Logistic Regression Predicting Experience Match Upon Posting to Centre

\begin{tabular}{|c|c|c|c|c|c|}
\hline & Personnel & Commerce & Finance & Industries & Home \\
\hline \multirow[t]{2}{*}{ Age } & -0.0302 & 0.0313 & 0.0507 & 0.0159 & -0.0162 \\
\hline & $(0.0206)$ & $(0.0178)$ & $(0.0343)$ & $(0.0401)$ & $(0.0401)$ \\
\hline \multirow[t]{2}{*}{ Postings } & -0.0134 & -0.0410 & -0.0963 & -0.0429 & 0.0335 \\
\hline & $(0.0156)$ & $(0.0370)$ & $(0.0573)$ & $(0.0798)$ & $(0.0634)$ \\
\hline \multirow[t]{2}{*}{ Female } & $-0.617^{* *}$ & -0.490 & -0.261 & -0.227 & $-0.626^{*}$ \\
\hline & $(0.202)$ & $(0.463)$ & $(0.237)$ & $(0.544)$ & $(0.262)$ \\
\hline \multirow[t]{2}{*}{ First Division } & $0.248^{*}$ & 0.126 & $0.659^{*}$ & $0.284^{* *}$ & -0.384 \\
\hline & $(0.116)$ & $(0.233)$ & $(0.256)$ & $(0.0976)$ & $(0.198)$ \\
\hline \multirow[t]{2}{*}{ Specialization } & 0.213 & 0.0679 & $-0.583^{*}$ & 0.0659 & 0.312 \\
\hline & $(0.185)$ & $(0.331)$ & $(0.228)$ & $(0.372)$ & $(0.380)$ \\
\hline \multirow[t]{2}{*}{ Personnel } & -0.127 & $1.111^{*}$ & -0.569 & $-13.99^{* * *}$ & $1.290^{*}$ \\
\hline & $(0.521)$ & $(0.503)$ & $(1.056)$ & $(0.544)$ & $(0.522)$ \\
\hline \multirow[t]{2}{*}{ Commerce } & $1.137^{* * *}$ & $-13.68^{* * *}$ & $-13.74^{* * *}$ & $-13.89^{* * *}$ & $-14.05^{* * *}$ \\
\hline & $(0.200)$ & $(1.113)$ & $(1.149)$ & $(1.170)$ & $(1.062)$ \\
\hline \multirow[t]{2}{*}{ Finance } & 0.179 & 0.610 & $1.011^{* *}$ & 0.0322 & -0.836 \\
\hline & $(0.262)$ & $(0.350)$ & $(0.357)$ & $(0.919)$ & $(0.744)$ \\
\hline \multirow[t]{2}{*}{ Industries } & -0.00599 & 0.270 & $0.869^{* *}$ & 0.406 & -0.150 \\
\hline & $(0.229)$ & $(0.596)$ & $(0.314)$ & $(0.403)$ & $(0.843)$ \\
\hline \multirow[t]{2}{*}{ Home } & $-14.63^{* * *}$ & $-14.45^{* * *}$ & 0.361 & $-14.62^{* * *}$ & 0.748 \\
\hline & $(0.716)$ & $(0.652)$ & $(1.372)$ & $(0.758)$ & $(0.579)$ \\
\hline \multirow[t]{2}{*}{$\mathrm{P}$ (Promotion to Centre) } & -8.528 & 7.068 & $-10.62^{*}$ & $-17.67^{* * *}$ & 4.690 \\
\hline & $(7.150)$ & $(4.855)$ & $(4.559)$ & $(4.911)$ & $(2.951)$ \\
\hline \multirow[t]{2}{*}{ Constant } & 0.764 & $-2.708^{* *}$ & $-4.447^{* * *}$ & -2.152 & -0.905 \\
\hline & $(1.071)$ & $(0.845)$ & $(1.132)$ & $(1.571)$ & $(1.579)$ \\
\hline Observations & & & 1350 & & \\
\hline Log-Likelihood & & & -1924.7 & & \\
\hline
\end{tabular}

Standard errors in parentheses

Standard errors for all models are clustered at the cadre level.

${ }^{*} p<0.05,{ }^{* *} p<0.01,{ }^{* * *} p<0.001$ 
Table 8: Logistic Regression Predicting Empanelment as Joint Secretary

\begin{tabular}{|c|c|c|c|c|}
\hline & (1) & (2) & (3) & (4) \\
\hline \multirow[t]{2}{*}{ Postings } & $0.285^{* *}$ & $0.324^{* * *}$ & $0.324^{* * *}$ & $0.273^{* *}$ \\
\hline & $(0.0947)$ & $(0.0946)$ & $(0.0945)$ & $(0.0953)$ \\
\hline \multirow[t]{2}{*}{$(\text { Postings })^{2}$} & $-0.00774^{*}$ & $-0.00833^{*}$ & $-0.00832^{*}$ & -0.00621 \\
\hline & $(0.00366)$ & $(0.00363)$ & $(0.00363)$ & $(0.00356)$ \\
\hline \multirow[t]{2}{*}{ Age } & $4.959^{* * *}$ & $5.012^{* * *}$ & $5.014^{* * *}$ & $5.149^{* * *}$ \\
\hline & $(0.416)$ & $(0.416)$ & $(0.416)$ & $(0.436)$ \\
\hline \multirow[t]{2}{*}{$(\text { Age })^{2}$} & $-0.0497^{* * *}$ & $-0.0500^{* * *}$ & $-0.0500^{* * *}$ & $-0.0512^{* * *}$ \\
\hline & $(0.00444)$ & $(0.00445)$ & $(0.00445)$ & $(0.00466)$ \\
\hline \multirow[t]{2}{*}{ Tenure } & $-0.00914^{*}$ & $-0.00895^{*}$ & $-0.00897^{*}$ & $-0.0175^{* *}$ \\
\hline & $(0.00360)$ & $(0.00358)$ & $(0.00358)$ & $(0.00535)$ \\
\hline \multirow[t]{2}{*}{ Specialization } & $0.929^{* * *}$ & $1.085^{* * *}$ & $1.086^{* * *}$ & 0.495 \\
\hline & $(0.267)$ & $(0.273)$ & $(0.273)$ & $(0.382)$ \\
\hline \multirow[t]{2}{*}{ Female } & 0.101 & 0.174 & 0.174 & 0.267 \\
\hline & $(0.203)$ & $(0.203)$ & $(0.203)$ & $(0.232)$ \\
\hline \multirow[t]{2}{*}{ Hindi } & $0.364^{*}$ & $0.494^{* *}$ & $0.493^{* *}$ & $0.500^{* *}$ \\
\hline & $(0.154)$ & $(0.159)$ & $(0.159)$ & $(0.175)$ \\
\hline \multirow[t]{2}{*}{ Bengali } & 0.439 & 0.524 & 0.524 & 0.484 \\
\hline & $(0.266)$ & $(0.275)$ & $(0.275)$ & $(0.305)$ \\
\hline \multirow[t]{2}{*}{ Telugu } & -0.570 & -0.487 & -0.488 & -0.439 \\
\hline & $(0.345)$ & $(0.349)$ & $(0.349)$ & $(0.361)$ \\
\hline \multirow[t]{2}{*}{ Marathi } & 0.510 & 0.513 & 0.513 & 0.622 \\
\hline & $(0.546)$ & $(0.552)$ & $(0.551)$ & $(0.555)$ \\
\hline \multirow[t]{2}{*}{ Tamil } & -0.193 & 0.0341 & 0.0334 & -0.0517 \\
\hline & $(0.254)$ & $(0.259)$ & $(0.259)$ & $(0.287)$ \\
\hline \multirow[t]{2}{*}{ First Division } & $0.714^{* * *}$ & $0.806^{* * *}$ & $0.806^{* * *}$ & $0.777^{* * *}$ \\
\hline & $(0.140)$ & $(0.142)$ & $(0.142)$ & $(0.152)$ \\
\hline \multirow[t]{2}{*}{ Engineering } & 0.0979 & 0.117 & 0.118 & 0.135 \\
\hline & $(0.233)$ & $(0.240)$ & $(0.240)$ & $(0.247)$ \\
\hline \multirow[t]{2}{*}{ Humanities } & -0.0812 & -0.135 & -0.135 & -0.180 \\
\hline & $(0.217)$ & $(0.218)$ & $(0.218)$ & $(0.231)$ \\
\hline \multirow[t]{2}{*}{ Medicine } & -0.205 & -0.265 & -0.265 & 0.123 \\
\hline & $(0.533)$ & $(0.526)$ & $(0.526)$ & $(0.529)$ \\
\hline \multirow[t]{2}{*}{ Professional } & -0.0154 & 0.00239 & 0.00262 & 0.143 \\
\hline & $(0.200)$ & $(0.202)$ & $(0.202)$ & $(0.206)$ \\
\hline \multirow[t]{2}{*}{ Science } & -0.117 & -0.163 & -0.163 & -0.130 \\
\hline & $(0.173)$ & $(0.174)$ & $(0.174)$ & $(0.180)$ \\
\hline \multirow[t]{2}{*}{ Business } & -0.211 & -0.221 & -0.221 & -0.206 \\
\hline & $(0.188)$ & $(0.189)$ & $(0.189)$ & $(0.203)$ \\
\hline \multirow[t]{2}{*}{ Law } & 0.159 & 0.0535 & 0.0532 & 0.165 \\
\hline & $(0.245)$ & $(0.244)$ & $(0.244)$ & $(0.263)$ \\
\hline \multirow[t]{2}{*}{ No. of Subjects } & 0.0454 & 0.103 & 0.103 & 0.0406 \\
\hline & $(0.145)$ & $(0.146)$ & $(0.146)$ & $(0.153)$ \\
\hline Two degrees & 0.371 & 0.402 & 0.403 & 0.412 \\
\hline
\end{tabular}




\begin{tabular}{lcccc}
\hline & $(0.253)$ & $(0.260)$ & $(0.260)$ & $(0.264)$ \\
Three degrees & $0.646^{*}$ & $0.708^{*}$ & $0.708^{*}$ & $0.790^{* *}$ \\
& $(0.275)$ & $(0.282)$ & $(0.282)$ & $(0.299)$ \\
Four degrees & $0.688^{*}$ & $0.769^{*}$ & $0.770^{*}$ & $0.852^{*}$ \\
& $(0.327)$ & $(0.333)$ & $(0.333)$ & $(0.355)$ \\
P(Promotion to Centre) & & $-20.16^{* * *}$ & $-20.17^{* * *}$ & $-20.45^{* * *}$ \\
& & $(5.873)$ & $(5.874)$ & $(6.112)$ \\
New Chief Minister & & & 0.0960 & 0.108 \\
& & & $(0.202)$ & $(0.203)$ \\
Depth of experience & $\mathrm{N}$ & $\mathrm{N}$ & $\mathrm{N}$ & $\mathrm{Y}$ \\
Cadre F.E.s & $\mathrm{Y}$ & $\mathrm{Y}$ & $\mathrm{Y}$ & $\mathrm{Y}$ \\
Cohort F.E.s & $\mathrm{Y}$ & $\mathrm{Y}$ & $\mathrm{Y}$ & $\mathrm{Y}$ \\
Year F.E.s & $\mathrm{Y}$ & $\mathrm{Y}$ & $\mathrm{Y}$ & $\mathrm{Y}$ \\
\hline Observations & 139075 & 139075 & 139075 & 138058 \\
Log-Likelihood & -2426.2 & -2416.8 & -2416.7 & -2361.5 \\
\hline \hline
\end{tabular}

Standard errors in parentheses

${ }^{*} p<0.05,{ }^{* *} p<0.01,{ }^{* * *} p<0.001$

Column 1 introduces all controls from columns 1 through 4 of table 5 .

The effect of specialization is robust to the exclusion of these controls. A larger table breaking out these groups of controls is available on request. 
Table 9: Multinomial Logistic Regression Predicting Experience Match Upon Empanelment

\begin{tabular}{|c|c|c|c|c|}
\hline & Finance & Industries & Home & Personnel \\
\hline \multirow[t]{2}{*}{ Age } & -0.0208 & -0.0533 & 0.0884 & -0.0723 \\
\hline & $(0.0396)$ & $(0.0589)$ & $(0.0542)$ & $(0.0684)$ \\
\hline \multirow[t]{2}{*}{ Postings } & $-0.0968^{*}$ & -0.0493 & -0.0901 & -0.00229 \\
\hline & $(0.0469)$ & $(0.0603)$ & $(0.0626)$ & $(0.0856)$ \\
\hline \multirow[t]{2}{*}{ Female } & -0.515 & -0.402 & 0.138 & -0.661 \\
\hline & $(0.518)$ & $(0.526)$ & $(0.646)$ & $(0.715)$ \\
\hline \multirow[t]{2}{*}{ First Division } & 0.0679 & 0.0523 & 0.0374 & 0.204 \\
\hline & $(0.311)$ & $(0.341)$ & $(0.448)$ & $(0.339)$ \\
\hline \multirow[t]{2}{*}{ Specialization } & -0.800 & -0.0541 & 0.144 & -0.620 \\
\hline & $(0.733)$ & $(0.848)$ & $(0.765)$ & $(1.005)$ \\
\hline \multirow[t]{2}{*}{ Finance } & $3.284^{* * *}$ & 0.729 & 0.466 & 0.903 \\
\hline & $(0.472)$ & $(0.566)$ & $(0.784)$ & $(0.621)$ \\
\hline \multirow[t]{2}{*}{ Industries } & 0.741 & $2.515^{* * *}$ & 0.411 & $-13.57^{* * *}$ \\
\hline & $(0.682)$ & $(0.413)$ & $(0.822)$ & $(0.416)$ \\
\hline \multirow[t]{2}{*}{ Home } & $-23.26^{* * *}$ & 0.519 & $3.502^{* * *}$ & $-23.73^{* * *}$ \\
\hline & $(0.490)$ & $(1.043)$ & $(0.595)$ & $(0.556)$ \\
\hline \multirow[t]{2}{*}{ Personnel } & $1.250^{*}$ & $0.878^{*}$ & $0.807^{*}$ & $2.002^{* *}$ \\
\hline & $(0.490)$ & $(0.447)$ & $(0.371)$ & $(0.660)$ \\
\hline \multirow[t]{2}{*}{$\mathrm{P}$ (Empanelment) } & -50.39 & -20.20 & 10.31 & -3.340 \\
\hline & $(27.93)$ & $(19.88)$ & (13.08) & $(45.80)$ \\
\hline \multirow[t]{2}{*}{ Constant } & -1.669 & 0.517 & -5.842 & -0.555 \\
\hline & $(1.831)$ & $(3.485)$ & $(2.986)$ & $(3.762)$ \\
\hline Observations & \multicolumn{4}{|c|}{486} \\
\hline Log-Likelihood & \multicolumn{4}{|c|}{-451.9} \\
\hline
\end{tabular}

Standard errors in parentheses

Standard errors for all models are clustered at the cadre level.

${ }^{*} p<0.05,{ }^{* *} p<0.01,{ }^{* * *} p<0.001$ 